\title{
Daphnoretin from Carthamus tinctorius as a Potential Inflammatory Inhibitor in COVID-19 by Binding to Toll-like Receptor-4: An in silico Molecular Docking Study
}

\author{
Lismayana Hansur ${ }^{1,2}$, Melva Louisa ${ }^{3 *}$, Puspita Eka Wuyung ${ }^{4,5}$, Fadilah Fadilah ${ }^{6,7}$ \\ ${ }^{1}$ Doctoral Program in Biomedical Sciences, Faculty of Medicine, Universitas Indonesia, Jakarta, Indonesia; ${ }^{2}$ Department of \\ Microbiology, Faculty of Medicine, Universitas Muhammadiyah Makassar, Makassar, Indonesia; ${ }^{3}$ Department of Pharmacology \\ and Therapeutics, Faculty of Medicine, Universitas Indonesia, Jakarta, Indonesia; ${ }^{4}$ Department of Pathological Anatomy, \\ Faculty of Medicine, Universitas Indonesia, Jakarta, Indonesia; ${ }^{5}$ Animal Research Facility, Indonesian Medical Education and \\ Research Institute, Universitas Indonesia, Jakarta, Indonesia; ${ }^{6}$ Department of Chemistry, Faculty of Medicine, Universitas \\ Indonesia, Jakarta, Indonesia; ${ }^{7}$ Bioinformatics Core Facilities Cluster, Indonesian Medical Education and Research Institute \\ (IMERI), Universitas Indonesia, Jakarta, Indonesia
}

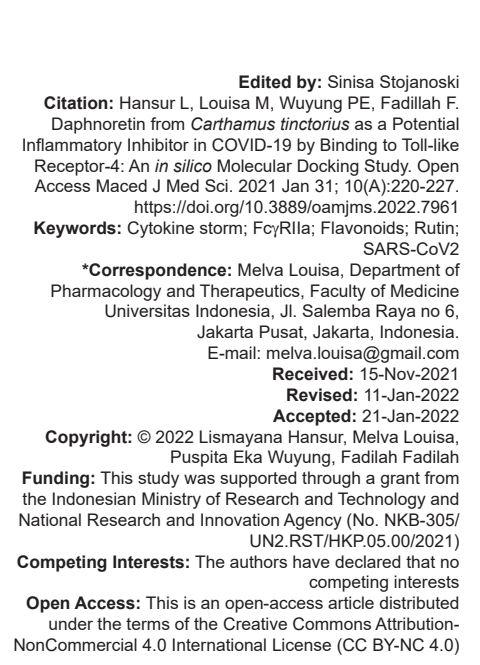

\section{Abstract}

BACKGROUND: Cytokine storm in COVID-19 patients has contributed to many morbidities and mortalities in patients Studies have found that toll-like receptors (TLRs) and some Fc receptors play essential roles in the hyperactivation of the immune system. Up to date, researchers are still in progress to discover effective and safe drugs to alleviate the hyperinflammatory state in COVID-19. The previous studies had shown that Carthamus tinctorius and its bioactive compounds might have anti-inflammatory activities in animal models.

AIM: We aimed to investigate the possible interactions of several flavonoids from $C$. tinctorius with several immune system components using a biocomputational approach.

METHODS: Molecular docking was done using the AutoDock program based on the Kyoto Encyclopedia of Genes and Genomes (KEGG) COVID-19 pathway. The most suitable receptors found were studied to study the interactions with several flavonoids from $C$. tinctorius.

RESULTS: TLR4, TLR8, and FcyRIla were found to bind with SARS CoV2 inflammatory pathway and further selected as macromolecules for potential interactions study with 22 flavonoids from $C$. tinctorius. Of the 22 flavonoids studied daphnoretin showed the best binding affinity with TLR4 and Rutin was shown to attach best with FcyRlla. Unlike its excellent binding to TLR4, daphnoretin showed weak binding to TLR8.

CONCLUSION: Daphnoretin showed an excellent affinity with TLR4 and might be a good candidate as an inhibitor in hyperinflammatory reactions in COVID-19 DTLR8.

\section{Introduction}

SARS-CoV-2 is a virus that mainly attacks the lung's airway, alveolar, vascular endothelium, and macrophages, which is distinguished by an aggressive inflammatory response from the host [1]. The overexpression of early response pro-inflammatory cytokines (tumor necrosis factor-alpha (TNF- $\alpha$ ) and interleukins (IL- 6 and IL-1 $\beta$ ) by innate immune results manifests as a cytokine storm [2]. COVID-19 individuals have a higher risk of vascular hyperpermeability due to these variables and multiorgan failure, severe systemic damage, and finally, death when the high levels of cytokines are not reduced [3]. The innate immune response involves releasing cytokines and chemokines, essential for detecting and managing infections [4].
Toll-like receptors (TLRs) and several receptors are essential in initiating innate immune responses by producing inflammatory cytokines, Type I interferons (IFN), and other mediators [5]. However, it was suggested that the severe form of COVID-19 is characterized by an abnormal and exacerbated immunological host response. Exacerbation of hyperinflammatory response is mainly associated with adverse outcomes in many patients, particularly with comorbidities such as obesity or diabetes, high blood pressure, or atherosclerosis [6]. A variety of adaptors, including myeloid differentiation primary response protein (MyD88), Toll//L-1 receptor domain-containing adaptor protein (TIRAP/Mal), TIR-domain-containing adaptor inducing interferon- $\beta$ (TRIF), and TRIF-related adaptor molecule, is involved in TLR signaling pathways that are tightly controlled. TLR-mediated pathways have 
been reported to have a significant role in inflammatory illness, modulating host defense against infections, and immunological diseases [7].

A previous research had demonstrated an association between TLR2 and MyD88 expressions with COVID-19 severity [8]. TLR2 and MyD88 were necessary to produce coronavirus-induced inflammation, although TLR2-dependent signaling triggered the production of pro-inflammatory cytokines irrespective of viral entry [4]. TLR7 and TLR8 were also suggested to be linked with hyperinflammatory reactions in COVID-19 [9].

Activating innate immunity, regulating cytokine production, and starting the adaptive immune system are vital functions of TLRs. The body's innate immune system plays a crucial role in the defense against infections. Pathways activated by TLRs may have a role in the pathophysiology of SARS CoV2 [5]. Notably, several TLRs are associated with hyperinflammatory processes in COVID-19. A simplified theory suggested that pathogenic components that activate TLR4 produce proinflammatory cytokines through the traditional signaling route and/or Type I IFNs and anti-inflammatory cytokines through the alternative signaling. Overstimulation of TLR4 may lead to hyperinflammation [6], [8].

TLRs are not the only regulators in the activation of hyperinflammatory reactions. The Fc domains of antibodies may also interact with FcRs to enhance inflammation and exacerbate sickness symptoms [10]. Either IgG responses might protect against infection or might not [8]. Exacerbation of COVID-19 was suggested linked to the activation of an Fc receptor, a protein found on the surface of cells. One of the activated Fc receptors is FcyRlla that boosts the production of inflammatory cytokines in monocytes in the presence of immunocomplexes (IL-6 and TNF- $\alpha$ ) [6], [11].

High-dose dexamethasone has been used in hospitalized patients of COVID-19 and was shown to reduce inflammatory reactions and disease severity. Nonetheless, dexamethasone treatment was linked to severe adverse drug reactions, including septic shock and invasive fungal infections [12], [13]. Therefore, up to date, researchers still searched for alternative antiinflammatory drugs for COVID-19.

Carthamus tinctorius, also known as safflower, plants that are native in many countries with dry and barren climates, has been used empirically in many diseases, including in respiratory diseases such as whooping cough and chronic bronchitis [14], [15]. The previous animal studies had five shown that Hydroxysafflor Yellow A (HSYA), a bioactive compound of $C$. tinctorius, may promote an anti-inflammatory state in afflicted tissues by boosting anti-inflammatory cytokines and M2 macrophages (an anti-inflammatory phenotype) [16], [17], [18], [19]. Due to the antiinflammatory effect of $C$. tinctorius in the animal model, we suggested that other HSYA or its other bioactive compounds might have the activity to suppress TLRs and FCy receptors in COVID-19. Therefore, we aimed to investigate the possible interactions of various bioactive compounds of $C$. tinctorius with TLRs and FcyRlla receptors using a biocomputational approach.

\section{Methods}

\section{Selection of receptors}

Receptors were selected based on the Kyoto encyclopedia of genes and genomes (KEGG) COVID-19 pathway as target receptor and their intersection on COVID-19-inflammatory pathway.

KEGG pathway analysis indicated several receptors on signaling pathways, including TLR2 receptor, TLR4 receptor, and FcyRIIA receptor. Intracellular receptor located on endosome, the Toll-like receptors (TLR7, TLR8, and TLR3). TLR3 was excluded from this research because, in the COVID-19 KEGG pathway, attachment of viral RNA to TLR3 leads to activation of TNF receptor associated factor 3 , followed by activation of IKK and IFN regulatory factor 3 (IRF3). IKK and IRF3 act as a transcription factor that leads to DNA activation for IFN- $\alpha / \beta$ (IFN- $\alpha / \beta)$ production, followed by IFN receptor and activation of JAK/STAT activation for antiviral production (Figure 1).

\section{Molecular docking and molecular interactions screening}

Data mining and preparation protein and macromolecule

All docking experiments were done by utilizing the AutoDock Vina software, with the optimized model serving as the docking target in all cases. Molecular docking was used to screen the binding molecules between the receptor-binding domains (RBD) of SARSCoV2 (6AJF). The data were downloaded on the Research Collaboratory for Structural Bioinformatics Protein Data Bank (RCSB PDB; https://www.rcsb.org/) and several inflammatory receptors based on the KEGG pathway on COVID-19 disease (TLR2/4, TLR 7/8, and FcyRIIA) on Figure 1. AutoDock tools were employed in the docking experiments. The positive binding was selected to screen the flavonoid derivative compounds from $C$. tinctorius. We used 22 flavonoid derivative compounds from $C$. tinctorius as a ligand. Potential antiinflammatory compounds were shown by the compelling relationship between molecules and receptor targets.

\section{preparation}

Data mining, ligand, and macromolecule

The ligands were bioactive compounds found from $C$. tinctorius. The PubChem database provided 


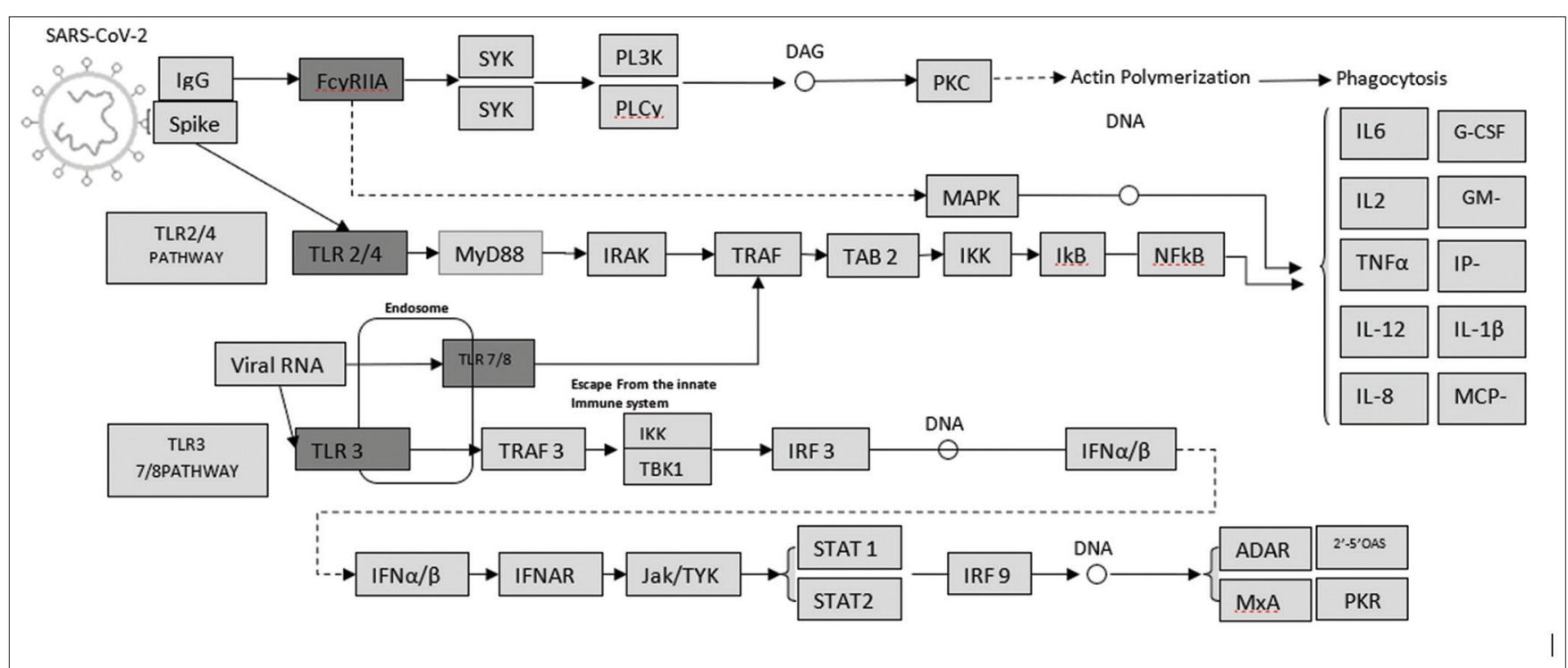

Figure 1: Molecular pathways in COVID-19 based on Kyoto encyclopedia of genes and genomes. Dark boxes showed receptors profoundly related to inflammation in COVID-19

the 3D models for these compounds (https://pubchem. ncbi.nlm.nih.gov/). Preparation of the compounds was accomplished using the Open Babel plugin integrated with PyRx, which minimized conformational energy and changed the file format from the.sdf format to the.pdb. Compounds used in the present study are shown in Table 1.

Table 1: Bioactive compounds found from Carthamus tinctorius used in the present biocomputational study

\begin{tabular}{lll}
\hline Name of compound & Molecular formula & PubChem ID \\
\hline Carthamin & $\mathrm{C} 43 \mathrm{H} 42 \mathrm{O} 22$ & 135565560 \\
Safflor yellow A & $\mathrm{C} 27 \mathrm{H} 30 \mathrm{O} 16$ & 71463725 \\
Safflor yellow B & $\mathrm{C} 48 \mathrm{H} 54 \mathrm{O} 27$ & 131751452 \\
Quercetin-3-O- $\beta$-D-glucoside & $\mathrm{C}_{21} \mathrm{H}_{19} \mathrm{O}_{12}$ & 25203368 \\
Saffloflavonesides B & & \\
Hydroxysafflor yellow A & $\mathrm{C} 21 \mathrm{H} 18 \mathrm{O}$ & 101878346 \\
Tinctormine & $\mathrm{C} 27 \mathrm{H} 32 \mathrm{O} 16$ & 6443665, \\
Safflomin C & $\mathrm{C} 27 \mathrm{H} 31 \mathrm{NO} 14$ & 42607657 \\
Saffloquinoside A & $\mathrm{C} 30 \mathrm{H} 30014$ & 42607658 \\
Saffloquinoside B & $\mathrm{C} 27 \mathrm{H} 30 \mathrm{O} 15$ & 45276863101501319131751684 \\
Cartormin & $\mathrm{C} 34 \mathrm{H} 38 \mathrm{O} 17$ & 5280343 \\
Quercetin & $\mathrm{C} 27 \mathrm{H} 29 \mathrm{NO} 1 \mathrm{C} 15 \mathrm{H} 10 \mathrm{O} 7$ & 5282102 \\
Kaempferol-3-O- $\beta$-D-glucoside & $\mathrm{C} 21 \mathrm{H} 20 \mathrm{O} 11$ & 5280443 \\
Apigenin & & \\
Scutellarein & $\mathrm{C}_{15} \mathrm{H}_{10} \mathrm{O}_{5}$ & 5281697 \\
Rutin & $\mathrm{C}_{15} \mathrm{H}_{10} \mathrm{O}_{6}$ & 5280805 \\
Kaempferol & $\mathrm{C} 27 \mathrm{H} 30 \mathrm{O} 16$ & 5280863 \\
6-Hydroxykaempferol & $\mathrm{C} 15 \mathrm{H} 10 \mathrm{O}$ & 5281638 \\
Isorhamnetin & $\mathrm{C} 15 \mathrm{H} 10 \mathrm{O} 7$ & 5281654 \\
Umbelliferone & $\mathrm{C} 16 \mathrm{H} 12 \mathrm{O} 7$ & 5281426 \\
Daphnoretin & $\mathrm{C} 9 \mathrm{H} 6 \mathrm{O} 3$ & 5281406 \\
Acacetin & $\mathrm{C} 19 \mathrm{H} 12 \mathrm{O} 7$ & 5280442 \\
& $\mathrm{C} 16 \mathrm{H} 12 \mathrm{O} 5$ & \\
\hline
\end{tabular}

PubChem database was used to acquire the structures of the inhibitor: C29 (TLR2 inhibitor) [20], TAK-242 (TLR4 inhibitor) [21], AT791 (TLR7 inhibitor) [22], CU-CPT9A (TLR8 inhibitor) [23], and pep-C7C1 (inhibitor of FcyRlla) [24]. The PEP Fold3 website (https://bioserv.rpbs.univ-paris-diderot.fr/ services/PEP-FOLD3/) was used for the simulation of 3D structure peptide of Pep-C7C1. Using PyRx's OpenBabel plugin, all inhibitors were constructed by reducing conformational energy and changing the file format.pdb.
The 3D structures of the proteins TLR2 (PDB ID: 6NIG), TLR4 (PDB ID: 3FXI), TLR7 (PDB ID: 7CYN), TLR8 (PDB ID: 5Z14), and FcyRIla (PDB ID: 1H9V) were obtained from the RCSB PDB database (https://www.rcsb.org/). The Biovia Discovery Studio 2019 software was used to remove water molecules and contaminant ligands from these proteins.

\section{visualization \\ Molecular docking and interaction}

The docking process between protein and compounds was carried out using the AutoDock Vina software integrated with PyRx. Docking was carried out by a specific method by directing the grid to the protein's active site. The docking results were visualized using the Bovia Discovery Studio 2019 software.

\section{Results}

Binding of the Spike RBD SARSCoV2 (6AJF) with the TLR2/4, TLR 7/8, and FC $\gamma R$ Ila

We investigated the possible interactions between SARS-CoV2 for TLR2/4, TLR 7/8, and FcyRlla. The docked molecule complexes studied were those involving the TLR2/4, TLR 7/8, and FcyRIla and different RBD of SARS-CoV2 (6AJF), the FcyRIla. RBD of SARS-CoV2 displayed the most robust interaction with a docking score of -1121.7 (Table 2), followed by TLR4 with a docking score of -843.1 . The docking results were closely related to the value of binding affinity and the type of chemical bond formed. 
Table 2: The binding energy of the SARS-CoV2 receptor binding domain and TLR2/4, TLR 7/8, and FcyRIla

\begin{tabular}{lllll}
\hline Ligand & Protein & $\begin{array}{l}\text { Binding affinity } \\
(\mathrm{kJ} / \mathrm{mol})\end{array}$ & $\begin{array}{l}\text { The number of chemical } \\
\text { interactions }\end{array}$ \\
\cline { 3 - 5 } & & & $\begin{array}{l}\text { Hydrogen } \\
\text { bond }\end{array}$ & $\begin{array}{l}\text { Hydrophobic } \\
\text { interaction }\end{array}$ \\
\hline Receptor binding & TLR2 & - & - & - \\
domain of SARS-CoV2 & TLR4 & -843.1 & 8 & 7 \\
& TLR7 & - & - & - \\
& TLR8 & -312 & - & 1 \\
& FcyRlla & -1121.7 & 9 & 2 \\
\hline
\end{tabular}

The docking results showed that the SARSCoV2 RBD protein interacted with TLR4, TLR8, and FcyRlla with binding affinity $-843.4,-312$, and $-1121.7 \mathrm{~kJ} / \mathrm{mol}$, respectively. This RBD protein could not form interactions with TLR2 and TLR7. The protein had the lowest affinity value when interacting with FcyRlla and created nine hydrogen proteins and two hydrophobic interactions (Table 2).

\section{Screening of interactions between} flavonoid derivatives found C. tinctorius with the

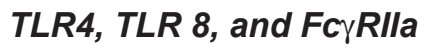

Binding affinity is the energy required to form a protein-ligand bond. The smaller the binding energy value, the easier it is for the ligand to bind to the protein. It means more potential affects the protein [25]. The chemical interactions formed from the docking are generally hydrogen bonds and hydrophobic interactions. Hydrogen bonding is the most vital type of intermolecular bonding and has high stability [26]. In addition, interactions between non-polar chemicals that cannot establish hydrogen bonds with water molecules are referred to as hydrophobic interactions. Hydrophobic bonds are the weakest type of chemical bond [27]. Table 3 shows the binding affinity values acquired from molecular docking between protein and flavonoids from $C$. tinctorius.

The 22 substances from $C$. tinctorius and TLR were done, 19 of which had a lower binding affinity than

Table 3: Binding energy interactions between and flavonoid derivative compound from $C$. tinctorius of TLR 4, TLR 8, and FcyRIla

\begin{tabular}{|c|c|c|c|}
\hline \multirow[t]{2}{*}{ Flavonoids from C. tinctorius } & \multicolumn{3}{|c|}{ Binding affinity $(\mathrm{kcal} / \mathrm{mol})$} \\
\hline & TLR4 & TLR8 & FcyRlla \\
\hline Positive control & -6.6 & -11.0 & -6.1 \\
\hline Carthamin & -8.7 & -3.6 & -5.3 \\
\hline Safflor yellow A & -7.3 & -5.4 & -4.8 \\
\hline Safflor yellow B & -5.2 & -3.0 & -4.2 \\
\hline Quercetin-3-O- $\beta$-D-glucoside & -7.0 & -6.9 & -4.9 \\
\hline Saffloflavonesides B & -8.4 & -8.3 & -5.7 \\
\hline Hydroxysafflor yellow A & -7.3 & -5.4 & -4.8 \\
\hline Tinctormine & -7.3 & -7.1 & -4.6 \\
\hline SafflominC & -7.5 & -6.4 & -4.4 \\
\hline Saffloquinoside A & -8.4 & -6.4 & -6.0 \\
\hline Saffloquinoside B & -4.6 & -6.2 & -5.0 \\
\hline Cartormin & -8.6 & -6.5 & -5.5 \\
\hline Quercetin & -7.8 & -8.7 & -5.1 \\
\hline Kaempferol-3-O- $\beta$-D-glucoside & -7.3 & -6.9 & -4.8 \\
\hline Apigenin & -8.2 & -10.1 & -4.9 \\
\hline Scutellarein & -8.1 & -9.5 & -5.1 \\
\hline Rutin & -7.4 & -6.7 & -6.1 \\
\hline Kaempferol & -7.4 & -9.6 & -5.1 \\
\hline 6-Hydroxykaempferol & -7.7 & -9.5 & -5.2 \\
\hline Isorhamnetin & -7.2 & -6.6 & -5.4 \\
\hline Umbelliferone & -6.5 & -8.5 & -4.7 \\
\hline Daphnoretin & -9.0 & -10.4 & -5.9 \\
\hline Acacetin & -7.6 & -10.3 & -4.7 \\
\hline
\end{tabular}

the inhibitor (TAK-242). We found that among the 22 compounds, daphnoretin needs relatively low energy on binding to TLR4 and TLR8, while the lowest energy was required on the binding of Rutin and FcyRlla (Table 3). Therefore, further analysis was done on the interactions between daphnoretin to TLR4 and TLR4 and Rutin to FcyRlla.

The binding of daphnoretin binds to TLR4 by two hydrogen bonds (Lys125 and Ser441) and four hydrophobic interactions (Ile80, Tyr131, and Ile153). Daphnoretin binds to the same amino acids as the inhibitor at Ile80, Tyr131, and Ile153 (Table 4). All compounds from C. tinctorius interact with TLR8 with a higher binding affinity value than the inhibitor (CU-CPT9A). The combination that has the lowest binding affinity value is daphnoretin $(-10.4 \mathrm{kcal} / \mathrm{mol})$. Daphnoretin interacts with TLR8 by forming two hydrogen bonds (Lys350 and Ser516) and three hydrophobic interactions (Ile403, Phe405, Phe495, and Ala518). Daphnoretin interacts with TLR8 in the same amino acids as the inhibitors in Lys350, Phe495, and Ala518 (Figure 2 and Table 4).

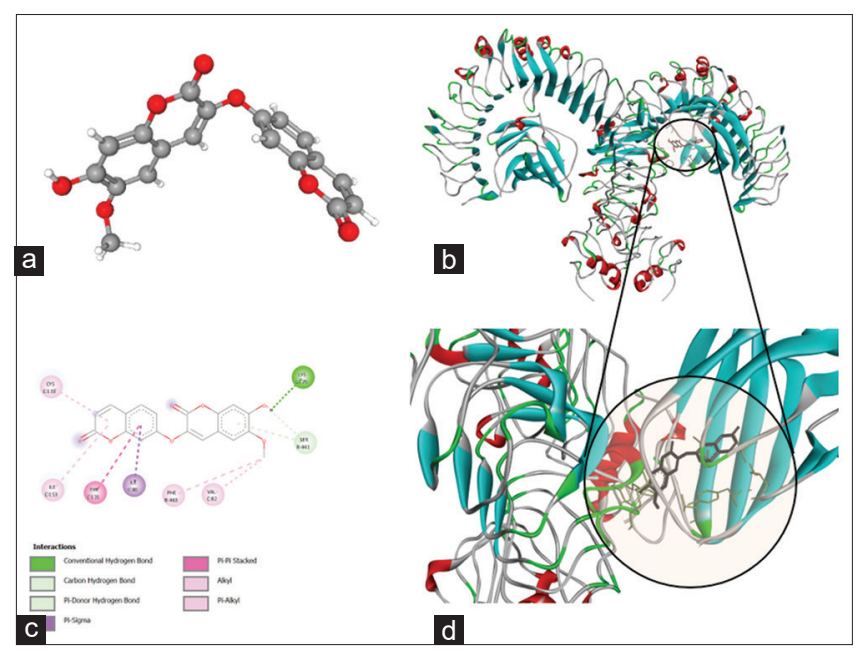

Figure 2: Diagrams of the daphnoretin and toll-like receptor (TLR)4 interactions. (a) The $3 D$ structure of daphnoretin. (b) TLR4 (PDIB ID: 3FXI) with daphnoretin as the ligand in the active binding site of $3 F X I$. (c) 2D docking pattern daphnoretin with amino acids Cys133, Lys125, Ile153, Tyr131, Phe463, Val82, and Ser441 of 3FXI. (d) 3D docking pattern and molecular interactions 3FXI with daphnoretin. Black dashed lines indicate the interactive bonds

Computational studies have been conducted to understand better how TLRs and Fc $\gamma$ RIla receptors bind to each other as inhibitor ligands. A promising impact on rational drug design has already been demonstrated by docking studies in ligand/receptor interactions. According to the analysis of the molecular docking, the interactions between daphnoretin and binding sites TLR4 are lowest than native ligand and higher than native ligan on the interaction between TLR 8. It indicated that the binding activity of daphnoretin and TLR4 was strong.

The docking results also showed that the compounds interacting with FcyRlla had a binding 
Table 4: Selected interactions between daphtoretin, rutin, and inhibitors

\begin{tabular}{lllll}
\hline Protein & Ligand & Binding affinity $(\mathrm{kcal} / \mathrm{mol})$ & Types of interactions & Hydrophobic interactions \\
\cline { 3 - 5 } & & & Hydrogen bond & Leu78, lle80, Leu54, Phe126, Tyr131, and Ile153 \\
\hline TLR4 & TAK-242 & -6.6 & Arg90 & Ile80, Tyr131, Cys133, and Ile153 \\
& Daphnoretin & -9.0 & Lys125 and Ser441 & Lys350, Phe261, Phe495, Val378, Ala518, and Tyr567 \\
TLR8 & CU-CPT9A & -11.0 & Val520 and Ser252 & Ile403, Phe405, Phe495, and Ala518 \\
& Daphnoretin & -10.4 & Lys350 and Ser516 & Trp110 and Lys113 \\
FcyRIla & Pep-C7C1 & -6.1 & Thr159, Ser161, Thr158, Glu86, and Trp87 & Leu88 and Phe160 \\
& Rutin & -6.1 & & \\
\hline
\end{tabular}

affinity equal to the inhibitor (Pep-C7C1). Rutin interacts with FcyRlla by forming four hydrogen bonds (Thr158, Trp87, Ser161, and Leu159) and two hydrophobic interactions (Leu88 and Phe160). Rutin interacts with FcyRlla on the same amino acids as the inhibitor at Thr158, Trp87, Ser161, and Leu159 (Table 4). A recommended chemical compound with these receptor targets is TLR4, with the most promising potential antagonist being daphnoretin.

\section{Discussion}

COVID-19 has caused deleterious outcomes in patients with the hyperinflammatory state [2]. Hyperinflammations can be caused by the overactivation of several immune systems, including TLRs and IgG responses through overproduction of FcyRlla [5], [11]. C. tinctorius and its bioactive compounds exert anti-inflammatory activities in several animal models [16], [17], [18], [19]. The present study aimed to determine the possible interactions of several flavonoids from C. tinctorius to TLRs and FcyRlla receptors using a biocomputational approach. We found that among the 22 flavonoids from $C$. tinctorius analyzed, daphnoretin needed the lowest energy to bind with TLR4 and TLR8, while Rutin used the lowest energy when binding to Fc $\gamma \mathrm{R}$ Ila.

On recognizing the host cells, SARS-CoV2 used the hosts' angiotensin-converting enzyme (ACE) to bind and enter host cells [28], [29]. The S1 subunit recognizes and then attaches two receptors to the ACE on the host cells. The two-heptad repeat domain of the S2 subunit is essential for creating a six-helical bundle during viral cell membrane fusion [28]. For ACE2 binding, the structural analysis highlighted highly conserved residues or has comparable side chain characteristics to those discovered in the SARS-CoV2 RBD [30].

On entering host cells, TLRs are essential in recognizing viral particles and activating the innate immune system. Inflammatory cytokines, including IL-1, IL-6, and TNF-alpha, are released when TLR pathways are activated. Many TLRs are essentially recognized as necessary in the inflammatory process in COVID19 [9]. TLR 2 and TLR 7 could not attach to the RBD protein (Table 1). The present study found that SARSCoV2 RBD (6AJF) is attached to The TLR 4, TLR 8, and
FcyRlla. Further investigations indicated a solid and stable binding interaction between the several protein epitopes and the TLR4. Following molecular docking studies, it was discovered that two peptides interacted with the SARS-CoV2 S1 receptor binding domain and the human TLR4 complex [31], [32], [33].

A different approach has been taken in several studies to search for potential vaccine candidates by targeting TLR4 to bind the epitope of the SARS-CoV2 spike protein [32], [34], [35]. Several studies on SARSCoV2 have shown the importance of TLR4 in generating an effective immune response [36], [37]. Interactions between the vaccine candidate and TLRs with the lowest energy score during molecular docking result in an immediate immune response and enable the targeted delivery of vaccine candidates into host cells [33]. Docking studies revealed that the vaccine candidate (Amino acid sequence of the $S$ protein's RBD) (PDB: $6 \mathrm{M} 17 \mathrm{~F}$ ) interacts with the TLR4 with solid affinity [33]. Our finding indicates that the TLR4 targets docking to search for epitope proteins for the vaccine candidate and receptor target for inhibitors or antagonistic to the receptor for uncontrolled inflammation, which leads to a cytokine storm.

In the present study, we selected 22 active compounds from $C$. tinctorius, to be the candidate for inhibitors in the COVID-19 hyperinflammatory condition. In silico approaches, mainly molecular docking was used to elucidate the potential compound network of COVID-19 anti-inflammatory and the critical signaling network of several compound treatments on this disease. The present study focuses on screening the interactions of the Spike RBD SARS-COV2 and TLR2/4, TLR 7/8, and FcyRlla as a receptor on the KEGG COVID-19 pathway. Afterward, the selection process of receptor binding between RBD SARSCOV2 (6AJF) and TLR2/4, TLR 7/8, and FcyRIIA. The use of TLR 4, TLR 8, and FcyRIIA was concluded based on binding energy. Then, the chosen macromolecule was molecularly docked with the flavonoid derivative compounds from $C$. tinctorius.

Furthermore, an iterative knowledge-based scoring mechanism examines all of the compound binding possibilities - the more negative the value, the higher the score for binding affinity. In total, 22 docked complexes of compounds and proteins were generated in this study. However, only three of the highest scoring docked complexes for each receptor were chosen for comparison (Table 3). The docking results showed that the compounds interacting with FcyRlla had a binding 
affinity equal to the inhibitor (Pep-C7C1). We found that out of the 22 compounds, daphnoretin has the most promising binding possibility with TLR4 and TLR8. The interactions between daphnoretin and binding sites TLR 4 are lowest than native ligand with hydrogen bond on Asam amino Lys125 and even higher than native ligan on the interaction between TLR8. The present result indicated that the binding activity of daphnoretin and TLR 4 was intense. As a result, daphnoretin was chosen to give the best interaction as an antagonist compared to the native ligand.

TLR4 contributes significantly to the overproduction of inflammatory cytokines. TLR4mediated inflammation that is uncontrolled has been linked to immunopathological outcomes in COVID19 patients. There is a link between TLR4 signaling and pathological inflammation during COVID-19 and contributes to developing therapeutic approaches targeting TLR4-mediated inflammation. TLR4 downstream signaling adapter molecules that they are CD14, MyD88, IL-1 receptor-associated kinase 1, TNFassociated factor 6 ; Toll//L-1 receptor domain-containing adaptor protein; TIR domain-containing adaptor molecule 1; and NF-kB were found to be overexpressed in peripheral blood mononuclear cells from SARSCoV2 patients [38]. The findings were supported by reports from COVID-19 patients exhibiting elevated levels of cytokines and chemokines, including IL2, IL7, IL10, GSCF, IP10, MCP1, MIP1A, and TNF $\alpha$ [39].

In silico analysis on the TLR-binding, ability of $S$ protein indicated cell surface TLR-S protein engagement and included hydrogen bonding and hydrophobic interactions. TLR4 has the strongest affinity for $\mathrm{S} 1$ of the $\mathrm{S}$ protein. Cell-surface TLRs, mainly TLR4, are most likely to recognize SARSCoV2 molecular patterns and initiate inflammatory responses [40]. TLR4 recognition of S protein may also result in receptor-dependent internalization, causing SARS-CoV2 infection in patients. SARS-CoV2 S protein is a PAMP that TLR4 recognizes and binds with through surface glycan and mannose carbohydrate motifs on the S1. This might explain why COVID-19 patients have higher TLR4 expression and inflammation [41]. TLR4 has been investigated in this research with binding with the RBD protein. As a result, TLR4 inhibition should be explored as a potential therapy in COVID-19 infection. As a result, targeting TLR4 interaction by providing competitive TLR4 antagonists might lead to a novel method of treating COVID19. Finally, daphnoretin is expected to improve immunobiology knowledge and could help inhibit spike protein binding on TLR-4. It will hope guided intervention strategy against inflammation or cytokine storm on COVID-19.

Daphnoretin inhibited CD1a, CD40, CD83, DC-SIGN, and HLA-DR expression in DCs. Daphnoretin inhibited DC allostimulation of naive CD4+CD45+RA+ T-cell proliferation. It induced atypical maturation of DCs with impaired allostimulatory function. This effect may be mediated by phosphorylated JNK [42]. Cell-associated protein kinase $\mathrm{C}$ activity increased in neutrophil suspension. Daphnoretin activated protein kinase C from resting neutrophils in the presence of $\mathrm{Ca} 2+$ and phosphatidylserine [43]. It can inhibit the proliferation, invasion, and migration of HCT116 and induce its apoptosis by modulating the Akt signal pathway's activity [44]. Daphnoretin might cause protein kinase $C$ to be activated, which activated NADPH oxidase and induced respiratory bursts [43]. Daphnoretin has been shown to possess anti-cancer activity [42]. The previous studies had also demonstrated daphnoretin potentials as antiviral and anti-tumor [45]. Our finding might be worth looking into its possibility as an inhibitor for inflammation by targeting TLR4 and TLR8.

\section{Conclusion}

Daphnoretin, an active flavonoid compound found from $C$. tinctorius, had a potent binding affinity with TLR4 and TLR8. These findings might be used as a basis for further investigations for daphnoretin as the possible inhibitors for hyperinflammatory conditions in COVID-19 by targeting TLRs.

\section{References}

1. Costela-Ruiz VJ, Illescas-Montes R, Puerta-Puerta JM, Ruiz C, Melguizo-Rodríguez L. SARS-CoV-2 infection: The role of cytokines in COVID-19 disease. Cytokine Growth Factor Rev. 2020;54:62-75. https://doi.org/10.1016/j.cytogfr.2020.06.001 PMid:32513566

2. Tang Y, Liu J, Zhang D, Xu Z, Ji J, Wen C. Cytokine storm in COVID-19: The current evidence and treatment strategies. Front Immunol. 2020;11:1708. https://doi.org/10.3389/ fimmu.2020.01708

PMid:32754163

3. Jose RJ, Manuel A. COVID-19 cytokine storm: The interplay between inflammation and coagulation. Lancet Respir Med. 2020;8(6):e46-7. https://doi.org/10.1016/ S2213-2600(20)30216-2

PMid:32353251

4. Zheng M, Karki R, Williams EP, Yang D, Fitzpatrick E, Vogel P, et al. TLR2 senses the SARS-CoV-2 envelope protein to produce inflammatory cytokines. Nat Immunol. 2021;22(7):829-38.

5. Onofrio L, Caraglia M, Facchini G, Margherita V, Placido S, Buonerba C. Toll-like receptors and COVID-19: A two-faced story with an exciting ending. Future Sci OA. 2020;6(8):Fso605. https://doi.org/10.2144/fsoa-2020-0091 PMid:32974046

6. Brandão SC, Ramos JO, Dompieri LT, Godoi ET, Figueiredo JL, Sarinho ES, et al. Is Toll-like receptor 4 involved in the severity of COVID-19 pathology in patients with cardiometabolic comorbidities? Cytokine Growth Factor Rev. 2021;58:102-10. https://doi.org/10.1016/j.cytogfr.2020.09.002 


\section{PMid:32988728}

7. Takeda K, Akira S. Toll-like receptors in innate immunity. In Immunol. 2005;17(1):1-14. https://doi.org/10.1093/intimm/dxh186 PMid:15585605

8. Aboudounya MM, Heads RJ. COVID-19 and toll-like receptor 4 (TLR4): SARS-CoV-2 may bind and activate TLR4 to increase ACE2 expression, facilitating entry and causing hyperinflammation. Mediat Inflamm. 2021;2021:8874339. https://doi.org/10.1155/2021/8874339 PMid:33505220

9. Khanmohammadi S, Rezaei N. Role of Toll-like receptors in the pathogenesis of COVID-19. J Med Virol. 2021;93(5):2735-9. https://doi.org/10.1002/jmv.26826 PMid:33506952

10. Chakraborty S, Edwards K, BuzzancoAS, Memoli MJ, Sherwood R, Mallajosyula V, et al. Symptomatic SARS-CoV-2 infections display specific IgG Fc structures. MedRxiv. 2020;2020:20103341.

11. Chakraborty S, Gonzalez J, Edwards K, Mallajosyula V, Buzzanco AS, Sherwood R, et al. Pro-inflammatory IgG Fc structures in patients with severe COVID-19. Nat Immunol. 2021; 22(1):67-73.

12. Lim WS, Emberson JR, Mafham M, Bell JL, Linsell L, Staplin N. Dexamethasone in hospitalized patients with COVID-19. N Engl J Med. 2020;384(8):693-704. https://doi.org/10.1056/ NEJMoa2021436 PMid:32678530

13. COVID STEROID 2 Trial Group. Effect of $12 \mathrm{mg}$ vs. $6 \mathrm{mg}$ of dexamethasone on the number of days alive without life support in adults with COVID-19 and severe hypoxemia: The COVID STEROID 2 randomized trial. JAMA 2021;326(18):1807-17. https://doi.org/10.1001/jama.2021.18295 PMid:34673895

14. Delshad E, Yousefi M, Sasannezhad $P$, Rakhshandeh $H$ Ayati Z. Medical uses of Carthamus tinctorius L. (Safflower): A comprehensive review from traditional medicine to modern medicine. Electron Physician. 2018;10(4):6672-81. https://doi. org/10.19082/6672

PMid:29881530

15. Wu X, Cai X, Ai J, Zhang C, Liu N, Gao W. Extraction, structures, bioactivities and structure-function analysis of the polysaccharides from safflower (Carthamus tinctorius L.). Front Pharmacol. 2021;12:767947. https://doi.org/10.3389/ fphar.2021.767947 PMid:34744747

16. Zhang Y, Song L, Pan R, Gao J, Zang BX, Jin M. Hydroxysafflor yellow a alleviates lipopolysaccharide-induced acute respiratory distress syndrome in mice. Biol Pharm Bull. 2017;40(2):135-44. https://doi.org/10.1248/bpb.b16-00329

PMid:28154251

17. Hansur L, Pawitan JA. The potential of hydroxysafflor yellow a as an adjuvant in COVID-19 patients with acute respiratory distress syndrome. Int Med J. 2021;28(5):527-31.

18. Sun CY, Pei CQ, Zang BX, Wang L, Jin M. The ability of hydroxysafflor yellow a to attenuate lipopolysaccharideinduced pulmonary inflammatory injury in mice. Phytother Res. 2010;24(12):1788-95.

19. Wang C, Huang Q, Wang C, Zhu X, Duan Y, Yuan S, et al. Hydroxysafflor yellow A suppresses oleic acidinduced acute lung injury via protein kinase A. Toxicol Appl Pharmacol. 2013;272(3):895-904. https://doi.org/10.1016/j. taap.2013.07.021

PMid:23933165

20. Mistry $P$, Laird MH, Schwarz RS, Greene S, Dyson T, Snyder GA, et al. Inhibition of TLR2 signaling by small molecule inhibitors targeting a pocket within the TLR2 TIR domain. Proc
Natl Acad Sci. 2015;112(17):5455-60. https://doi.org/10.1073/ pnas. 1422576112

PMid:25870276

21. Ono Y, Maejima Y, Saito M, Sakamoto K, Horita S, Shimomura K, et al. TAK-242, a specific inhibitor of Toll-like receptor 4 signalling, prevents endotoxemia-induced skeletal muscle wasting in mice. Sci Rep. 2020;10(1):694.

22. Lamphier M, Zheng W, Latz E, Spyvee M, Hansen H, Rose J, et al. Novel small molecule inhibitors of TLR7 and TLR9: Mechanism of action and efficacy in vivo. Mol Pharmacol. 2014;85(3):429-40. https://doi.org/10.1124/mol.113.089821 PMid:24342772

23. Hu Z, Tanji H, Jiang S, Zhang S, Koo K, Chan J, et al. Smallmolecule TLR8 antagonists via structure-based rational design. Cell Chem Biol. 2018;25(10):1286-91.e3

24. Cendron AC, Wines BD, Brownlee RT, Ramsland PA, Pietersz GA, Hogarth PM. A FcgammaRlla-binding peptide mimics the interaction between FcgammaRIla and IgG. Mol Immunol. 2008;45(2):307-19. https://doi.org/10.1016/j. molimm.2007.06.152

PMid:17673295

25. Pantsar T, Poso A. Binding affinity via docking: Fact and fiction. Molecules. 2018;23(8):1899. https://doi.org/10.3390/ molecules23081899

PMid:30061498

26. Arunan E, Desiraju GR, Klein RA, Sadlej J, Scheiner S, Alkorta I, et al. Defining the hydrogen bond: An account (IUPAC technical report). Pure Appl Chem. 2011;83(8):1619-36.

27. Otto S, Engberts JB. Hydrophobic interactions and chemica reactivity. Org Biomol Chem. 2003;1(16):2809-20. https://doi. org/10.1039/b305672d

PMid:12968330

28. Huang $\mathrm{Y}$, Yang $\mathrm{C}, \mathrm{Xu} \mathrm{XF}, \mathrm{Xu}$ W, Liu SW. Structural and functional properties of SARS-CoV-2 spike protein: Potential antivirus drug development for COVID-19. Acta Pharmacol Sin. 2020;41(9):1141-9.

29. Duan L, Zheng Q, Zhang H, Niu Y, Lou Y, Wang H. The SARSCoV-2 spike glycoprotein biosynthesis, structure, function, and antigenicity: Implications for the design of spike-based vaccine immunogens. Front Immunol. 2020;11(2593):576622. https:// doi.org/10.3389/fimmu.2020.576622

PMid:33117378

30. Lan J, Ge J, Yu J, Shan S, Zhou H, Fan S, et al. Structure of the SARS-CoV-2 spike receptor-binding domain bound to the ACE2 receptor. Nature. 2020;581(7807):215-20. https://doi. org/10.1038/s41586-020-2180-5

PMid:32225176

31. Padhi S, Sanjukta S, Chourasia R, Labala RK, Singh SP, Rai AK A multifunctional peptide from Bacillus fermented soybean for effective inhibition of SARS-CoV-2 S1 receptor binding domain and modulation of toll-like receptor 4: A molecular docking study. Front Mol Biosci. 2021;8(198):636647. https://doi.org/10.3389/ fmolb.2021.636647

PMid:33869283

32. Samad A, Ahammad F, Nain Z, Alam R, Imon RR, Hasan M, et al. Designing a multi-epitope vaccine against SARS-CoV-2: An immunoinformatics approach. J Biomol Struct Dyn. 2022; 40(1):14-30.

33. Jyotisha, Singh S, Qureshi IA. Multi-epitope vaccine against SARS-CoV-2 applying immunoinformatics and molecular dynamics simulation approaches. J Biomol Struct Dyn. 2020;2020:1-17.

34. Sanami S, Alizadeh M, Nosrati M, Dehkordi KA, AzadeganDehkordi F, Tahmasebian S, et al. Exploring SARS-COV-2 structural proteins to design a multi-epitope vaccine using 
immunoinformatics approach: An in silico study. Comput Biol Med. 2021;133:104390. https://doi.org/10.1016/j. compbiomed.2021.104390

PMid:33895459

35. Bhattacharya M, Sharma AR, Mallick B, Sharma G, Lee SS, Chakraborty C. Immunoinformatics approach to understanding molecular interaction between multi-epitopic regions of SARS-CoV-2 spike-protein with TLR4/MD-2 complex. Infect Genet Evol. 2020;85:104587. https://doi.org/10.1016/j. meegid.2020.104587

PMid:33039603

36. Dosch SF, Mahajan SD, Collins AR. SARS coronavirus spike protein-induced innate immune response occurs via activation of the NF-kappaB pathway in human monocyte macrophages in vitro. Virus Res. 2009;142(1-2):19-27. https:// doi.org/10.1016/j.virusres.2009.01.005

PMid:19185596

37. Kar T, Narsaria U, Basak S, Deb D, Castiglione F, Mueller DM, et al. A candidate multi-epitope vaccine against SARS-CoV-2. Sci Rep. 2020;10(1):10895.

38. Sohn KM, Lee SG, Kim HJ, Cheon S, Jeong H, Lee J, et al. COVID-19 patients upregulate toll-like receptor 4-mediated inflammatory signaling that mimics bacterial sepsis. J Korean Med Sci. 2020;35(38):e343. https://doi.org/10.3346/ jkms.2020.35.e343

PMid:32989935

39. Huang C, Wang Y, Li X, Ren L, Zhao J, Hu Y, et al. Clinical features of patients infected with 2019 novel coronavirus in Wuhan, China. Lancet. 2020;395(10223):497-506. https://doi. org/10.1016/S0140-6736(20)30183-5

PMid:31986264
40. Choudhury A, Mukherjee S. In silico studies on the comparative characterization of the interactions of SARS-CoV-2 spike glycoprotein with ACE-2 receptor homologs and human TLRs. J Med Virol. 2020;92(10):2105-13. https://doi.org/10.1002/ jmv.25987

PMid:32383269

41. Gadanec LK, McSweeney KR, Qaradakhi T, Ali B, Zulli A, Apostolopoulos V. Can SARS-CoV-2 virus use multiple receptors to enter host cells? Int J Mol Sci. 2021;22(3):992. https://doi.org/10.3390/ijms22030992

PMid:33498183

42. Chen CA, Liu CK, Hsu ML, Chi CW, Ko CC, Chen JS, et al. Daphnoretin modulates differentiation and maturation of human dendritic cells through down-regulation of c-Jun $\mathrm{N}$-terminal kinase. Int Immunopharmacol. 2017;51:25-30. https://doi. org/10.1016/j.intimp.2017.07.021 PMid:28772243

43. Wang JP, Raung SL, Kuo YH, Teng CM. Daphnoretin-induced respiratory burst in rat neutrophils is, probably, mainly through protein kinase C activation. Eur J Pharmacol. 1995;288(3):3418. https://doi.org/10.1016/0922-4106(95)90047-0 PMid: 7774678

44. Yu S, Guo H, Gao X, Li M, Bian H. Daphnoretin: An invasion inhibitor and apoptosis accelerator for colon cancer cells by regulating the Akt signal pathway. Biomed Pharmacother. 2019;111:1013-21.

45. Yang ZY, Kan JT, Cheng ZY, Wang XL, Zhu YZ, Guo W. Daphnoretin-induced apoptosis in HeLa cells: A possible mitochondria-dependent pathway. Cytotechnology. 2014;66(1):51-61. https://doi.org/10.1007/s10616-013-9536-8 PMid:24091880 